\title{
Selecting Bacillus spp. Antagonist of Fungal Phytopathogen Phytophthora infestans Causing Tomato Late Blight
}

\author{
Trang Le Vu Khanh ${ }^{1 * \#}$, Le Nguyen Tan ${ }^{1 \#}$, Mai Le Thi ${ }^{1}$, My Pham Thi ${ }^{1}$ \\ and Trieu Ly Hai ${ }^{2}$ \\ ${ }^{1}$ Faculty of Biology and Environmental Science, The University of Danang, \\ University of Science and Education, 459 Ton Duc Thang, Danang City, Vietnam. \\ ${ }^{2}$ Research Center of Ginseng and Medicinal Materials, National Institute of Medicinal Materials, \\ 41 Dinh Tien Hoang, Ho Chi Minh City, Vietnam.
}

\begin{abstract}
Authors' contributions
This work was carried out in collaboration among all authors. Authors TLVK and LNT designed the study, performed the statistical analysis, wrote the protocol and wrote the first draft of the manuscript. Authors MLT and MPT managed the analyses of the study. Author TLH managed the literature searches. All authors read and approved the final manuscript.

\section{Article Information}

DOI: 10.9734/ARRB/2020/v35i1230308

Editor(s):

(1) Dr. Manikant Tripathi, Dr. Ram Manohar Lohia Avadh University, India.

Reviewers:

(1) Isabela Leticia Pessenti, University Center of Maringá, Brazil.

(2) Uasley Caldas De Oliveira, University State of Feira de Santana, Brazil. Complete Peer review History: http://www.sdiarticle4.com/review-history/63056
\end{abstract}

Original Research Article

Received 10 September 2020

Accepted 14 November 2020

Published 09 December 2020

\begin{abstract}
The late blight caused by phytopathogen Phytophthora infestans has been one of the serious disease-causing yields and quality losses of tomato production in Vietnam. To control the fungal disease, chemical fungicides have been overused causing concerns about the ecological risks and human health, especially fungal resistance. Therefore, using natural products from beneficial microorganisms as a safer strategy is getting attention. The present study focused on the isolation of indigenous Bacillus sp. with potential antifungal activity against Phytophthora infestans with the aim to contribute to the diversification and improving the quality of biological control products Bacillus spp. in Vietnam. From 21 strains Bacillus spp. (marked BV1 - BV21) being isolated from different tomato farms in Danang City, Vietnam, Bacillus velezensis BV 16 was selected based on the most potential antagonistic strain in controlling fungal plant pathogen Phytophthora infestans attacking the tomato tree. The strongest inhibition of mycelial growth on P. infestans of Bacillus
\end{abstract}


velezensis BV16 was recorded with $88.89 \%$ of growth inhibition percentage. The results also showed that strong activity of chitinase, protease and cellulase in the BV16 strain are consistent with the novel growth control of Phytophthora infestans.

Keywords: Fungal disease; plant pathogen; antifungal activity; biological control.

\section{INTRODUCTION}

Tomato (Solanum lycopersicum) has been recognized as an important crop in many countries of the world based on high nutritional value and economic efficiency. Recently, Vietnam agricultural sector has focused on investment and development to improve productivity and quality of tomato. However, pathogenic diseases have been destructing the crop, in which, the late blight caused by phytopathogen Phytophthora infestans has been one of the serious disease-causing yields and quality losses of tomato production that can reduce yield by $40-70 \%$ of total tomato production. Phytophthora is an oomycete, not a true fungus, which produces zoospores, therefore control of Phytophthora pathogens differs from others by true fungi and different fungicides are used [1]. One of the major control measures for Phytophthora infestans is agrochemical applications, for example, phosphonate, which bring fast efficiency, unfortunately, resistance populations of Phytophthora infestans fungicide drugs have developed [2]. Furthermore, if excessive and unsystematic applications, agrichemicals become an obstacle to sustainable agriculture and pose threat to the environment and humans alike $[3,4,5]$. Several nations have enacted policies to regulate the usage volume and types of agriculture chemicals $[6,7]$. Therefore, finding alternative approaches are needed for effective crop protection against this pathogen.

One approach that has been receiving much attention is biological control using antagonists such as Trichoderma and Gliocladium, mycoparasitic Pythium spp., nonpathogenic Fusarium spp., binucleate Rhizoctonia spp., Laestisaria spp., Bacillus spp., fluorescent Pseudomonads and Streptomycetes [8]. The usage of these microbial biocontrol agents would not only bring long-term economic benefits but also contribute to sustainable and effective organic agriculture development because of their potential characteristics such as producing antimicrobial metabolites including lytic enzymes, antibiotics, cyanide as well as plant-growth promotion compounds [9].
Some bacteria strains such as Burkholderia, Pseudomonas, Bacillus with novel antagonistic activity have been received much attention because they produce a wide range of extracellular metabolites that can inhibit and control fungal plant pathogens [10]. Bacillus spp. is considered to be an expert among the most promising antagonistic bacteria strains. In the research of $\mathrm{Han}$ at al. [10], five bacterial strains LB01, LB14, HM03, HM17, and LB15, were characterized as having antifungal properties in the presence of Colletotrichum acutatum and C. gloeosporioides in South Korea, two important antagonistic traits, siderophore production and solubilization of insoluble phosphate, were observed in the three $B$. atrophaeus strains. Analyses of disease suppression revealed that LB14 was most effective for suppressing the incidence of anthracnose symptoms on pepper fruits. LB14 produced antagonistic compounds and suppressed conidial germination of $C$. acutatum and C. gloeosporioides.

To contribute to the diversification and improving the quality of biological control products Bacillus spp. in Vietnam, the present study was carried out to screen antagonistic bacterial strains Bacillus spp. from tomato plants based on measuring suppression of growth of Phytophthora infestans, select the strongest antagonistic strain and determine some biochemical properties of the selected isolate.

\section{MATERIALS AND METHODS}

\subsection{Collecting Samples}

Soil samples were collected from the tomato roots of both diseased and non-diseased plants, placed in the sterile polypropylene bags and kept at $4^{\circ} \mathrm{C}$, then transported to Laboratory for isolation of bacteria. Every separated bag containing $100 \mathrm{~g}$ of soil was recorded with name, date and location

\subsection{Isolation of Bacteria}

The collected soil sample was serially diluted by solution $\mathrm{NaCl}$ of $0.9 \%$ up to $10^{-7}$. Heating in a water bath at $80^{\circ} \mathrm{C}$ for 10 minutes was conducted to remove vegetative cells and other 
microorganisms. A drop of $100 \mu \mathrm{L}$ of dilution was spread on nutrient agar plate Luria-Bertani (LB) medium. The plates were incubated at $37^{\circ} \mathrm{C}$ for $24 \mathrm{~h}$. The particular colonies of Bacillus sp. were selected and sub-cultured in on nutrient agar plate until achieving pure colonies. The pure colonies were stored on nutrient agar slants (LB medium) at $4^{\circ} \mathrm{C}$. The identification of the genus was based on the morphology, gram staining and biochemical test of Bacillus sp.

\subsection{Antifungal Activity Assay}

Antifungal activity assay was imposed on a PDA plate with a center hole containing the fungal pathogen Phytophthora infestans and other holes at corners containing a volume of $20 \mu \mathrm{L}$ of bacteria overnight inoculate. All of the cultures were incubated at $30^{\circ} \mathrm{C}$. The growth of fungal pathogens was evaluated 7 days after incubation. Inhibition of fungal growth was measured as the distance of the clear zone between the bacterial colony and each fungus according to the following formula [10]:

$$
I=\frac{(R-r) 100}{R} \%
$$

In which, I was inhibition of mycelial growth (\%), $R$ and $r$ were the distance between the center and fungal hyphae edges in the control and treatment plates, respectively.

\subsection{Identification of Selected Strain Based on 16S Rrna Gene Sequencing}

DNA was extracted from the bacterial cells using a Wizard genomic DNA purification kit (Promega, USA). The 16S rRNA was amplified with the universal primers 27F (AGAGTTTGATCMTGGCTCAG), 1492R (TACGGYTACCTTGTTACGACTT), in Thermal Cycler Thermal Controller 2720 (Applied Biosystems, USA). PCR product was separated on gel agarose $1 \%$ and purified using GeneJET GelExtraction Kit (Thermo Scientific, USA). Sequencing of $16 S$ rRNA gene was performed by the Sanger's method, then using BLAST NCBI tanalysis to find the match sequence. The phylogenetic relationship was constructed by MEGA $X$ software using the nearest-neighbor data analysis method with 1000 bootstrap replicates.

\subsection{Extracellular Enzyme Assay of Selected Strain}

Chitinase activity was carried on YEG (Yeast extract glucose) medium agar (4 $\mathrm{g} / \mathrm{L}$ yeast extract, $20 \mathrm{~g} / \mathrm{L}$ glucose, $20 \mathrm{~g} / \mathrm{L}$ agar) adding $1 \%$ of colloidal chitin [11]. Chitin degrading ability was detected by development of a clear zone after incubation for 3 days at $25^{\circ} \mathrm{C}$.

Screening for extracellular cellulase production was carried out on agar plates containing $\mathrm{CMC}$ as substrate $\left(\left(1.0 \mathrm{~g} / \mathrm{L} \quad \mathrm{KH}_{2} \mathrm{PO}_{4}, \quad 0.5 \mathrm{~g} / \mathrm{L}\right.\right.$ $\mathrm{MgSO}_{4} \cdot 7 \mathrm{H}_{2} \mathrm{O}, \quad 0.5 \mathrm{~g} / \mathrm{L} \quad \mathrm{NaCl}, \quad 0.01 \mathrm{~g} / \mathrm{L}$ $\mathrm{FeSO}_{4} \cdot 7 \mathrm{H}_{2} \mathrm{O}, \quad 0.01 \mathrm{~g} / \mathrm{L} \quad \mathrm{MnSO}_{4} \cdot \mathrm{H}_{2} \mathrm{O}, \quad 0.3 \mathrm{~g}$ $\mathrm{NH}_{4} \mathrm{NO}_{3}, 10 \mathrm{~g} / \mathrm{L}$ carboxymethyl cellulose, $12 \mathrm{~g} / \mathrm{L}$ agar) media [12]. After incubation at $25^{\circ} \mathrm{C}$ for 3 days, the agar was flooded with $0.1 \%$ Congo red for $15 \mathrm{~min}$ to $20 \mathrm{~min}$, and then with $1 \mathrm{M} \mathrm{NaCl}$ for $15 \mathrm{~min}$ to $20 \mathrm{~min}$. The detection of the cellulolytic activity in these cases was achieved by staining of undigested $\mathrm{CMC}$ in plate regions which was not exposed to cellulolytic activity, while areas exposed to cellulase give clear halos surrounding the source of the enzyme.

Protease production of the bacterial strain was screened on agar plates supplemented with $5 \%$ $\mathrm{NaCl}$ and $1 \%$ casein (MNA). The plate was incubated overnight at $37{ }^{\circ} \mathrm{C}$. The protease producing strains were selected based on the zone of clearance [4].

\subsection{Statistical Analysis}

All experiments were performed in triplicate. The obtained results were shown as the average and standard deviation (SD). The excel software (2010) was used to analyze the obtained data. The significant test was set at $p \leq 0.05$.

\section{RESULTS AND DISCUSSION}

\subsection{Screening Antifungal Activity of Isolates}

In the present study, from soil samples of three tomato farms in Danang City, Vietnam, 21 strains were identified to have the emblematic morphology and biochemical characteristics of Bacillus sp. marked BV1 - BV21 (Table 1).

To selecting the isolate having the highest antagonistic capacity against Phytophthora infestans causing tomato late blight, antifungal activity assays of 21 isolates were carried ou. The obtained results showed that thirteen 
bacteria strains could inhibit the growth of $P$. infestans, in which six strains exhibited high antifungal activity including BV2, BV7, BV8, BV10, BV16, BV21 (Fig. 1). The strain BV16 exerted the strongest inhibition of mycelial growth on $P$. infestans, making up $88.89 \%$ of growth inhibition percentage which was $18.89 \%$ higher compare to eighteen Bacillus spp. and seven Pseudomonas spp. in the research of Caulier et al. [13]. Therefore, BV16 was selected to further study.

\subsection{Identification of Selected Strain Based on 16S Rrna Gene Sequencing}

To identify strain BV16 with the highest inhibitory effects on the growth of Phytophthora infestans, the 16rRNA sequences were analyzed. The obtained result revealed that BV16 displayed $99 \%$ sequence similarity with its closest relative Bacillus velezensis FZB42 (Fig. 2, Fig. 3).

Table 1. Biochemical charaterization of isolated strains

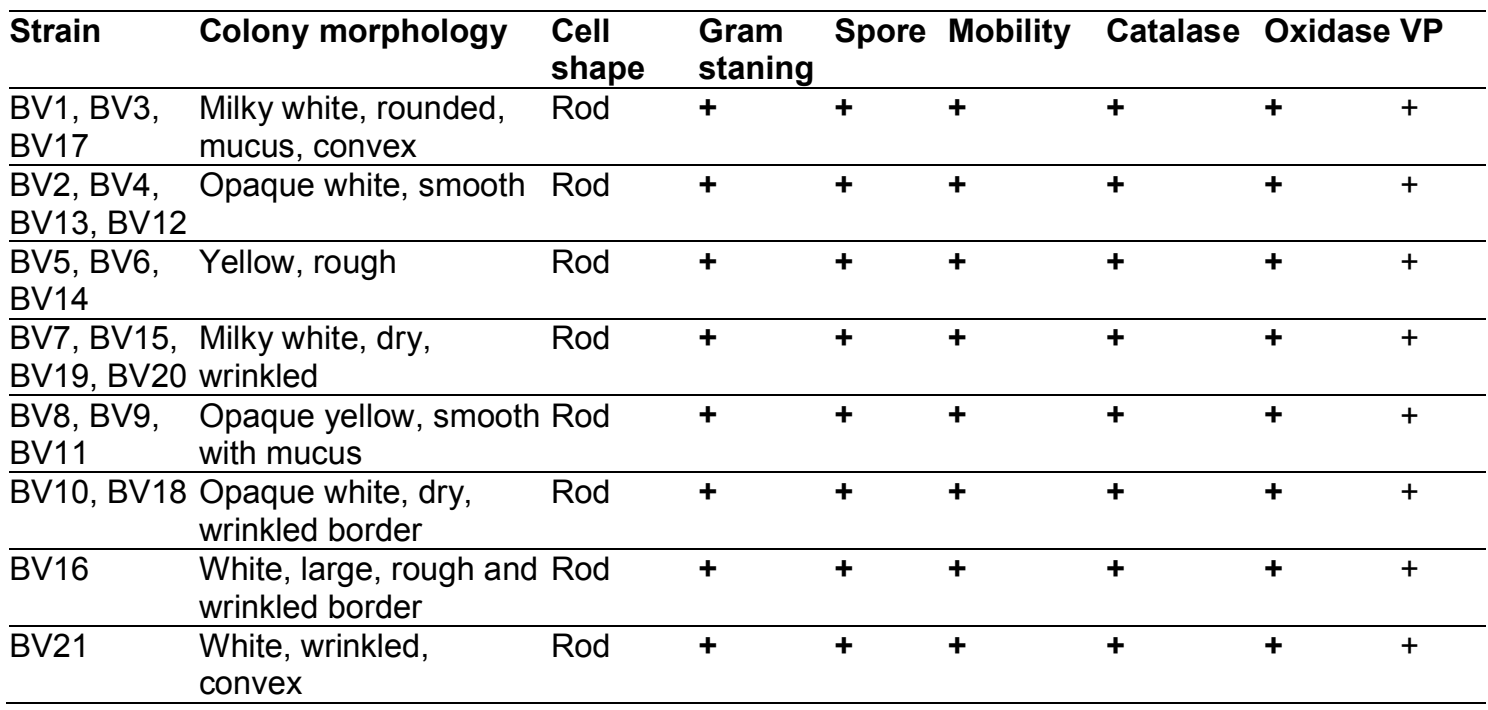
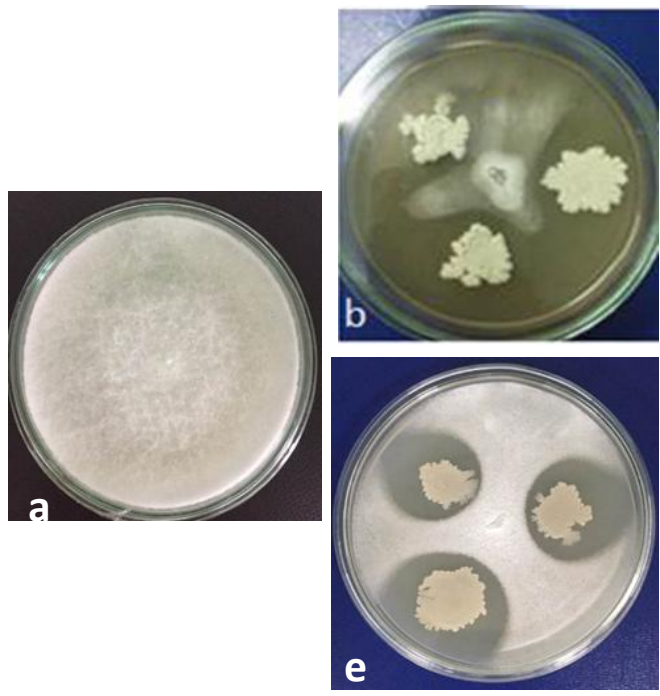
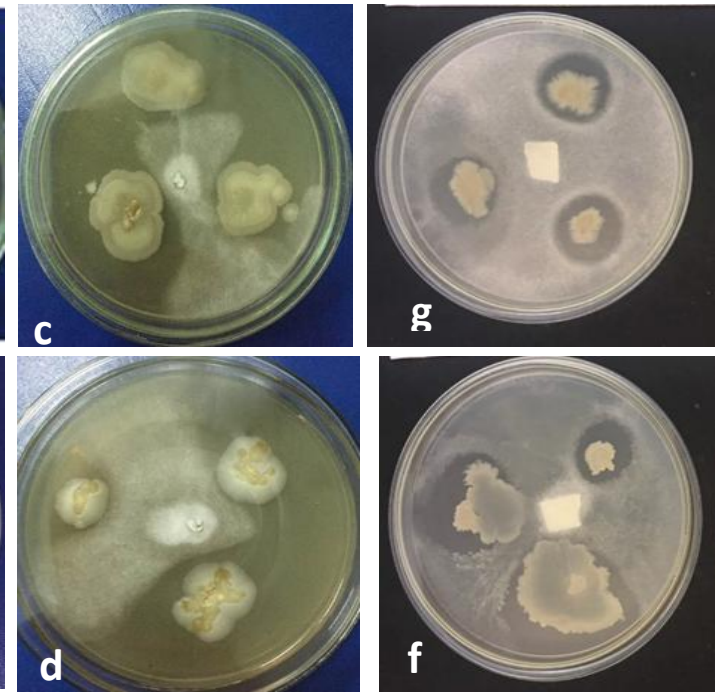

Fig. 1. Antifungal activity of isolated Bacillus strains

(a: Control, Antifungal activity of BV16 (b), BV21 (c), BV8 (f), BV2 (g), BV10 (d), BV7 (e) against Phytophthora infestans) 
Bacillus velezensis strain FZB42 16S ribosomal RNA, complete sequence, $99 \%$ identification
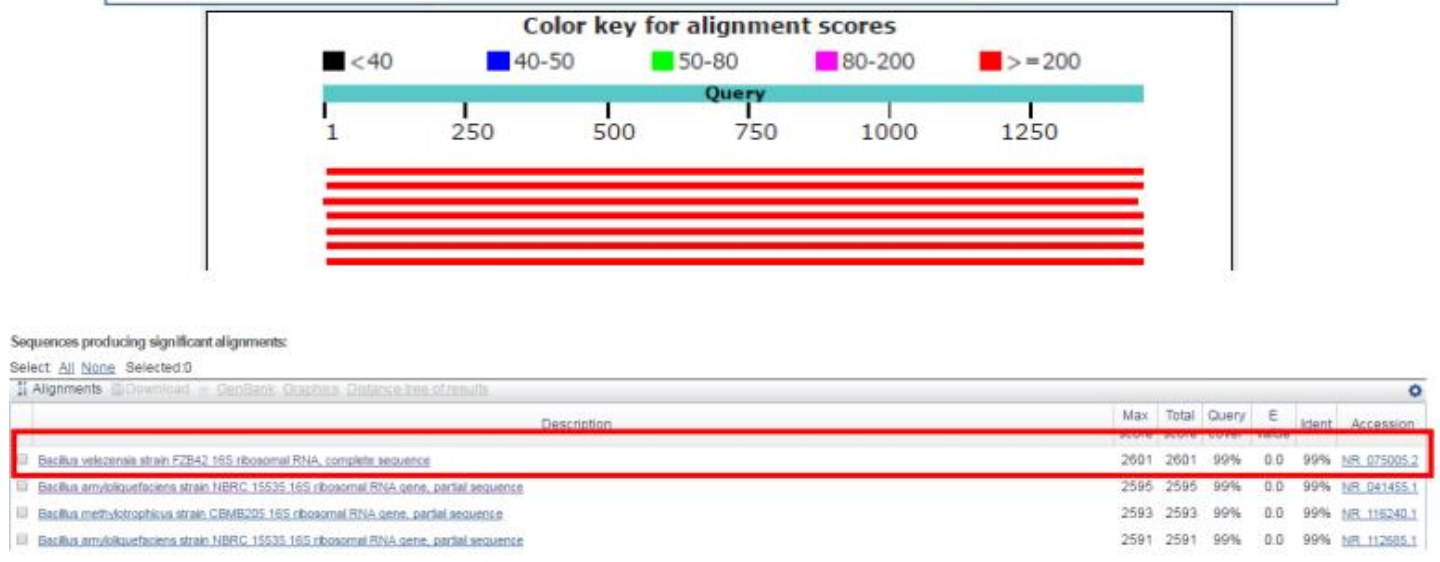

Bacillus velezensis strain FZB42 16 S ribosomal RNA, complete sequence Sequence ID: NR 075005.2 Length: 1550 Number of Matches: 1

Fig. 2. The result of the 16rRNA sequences

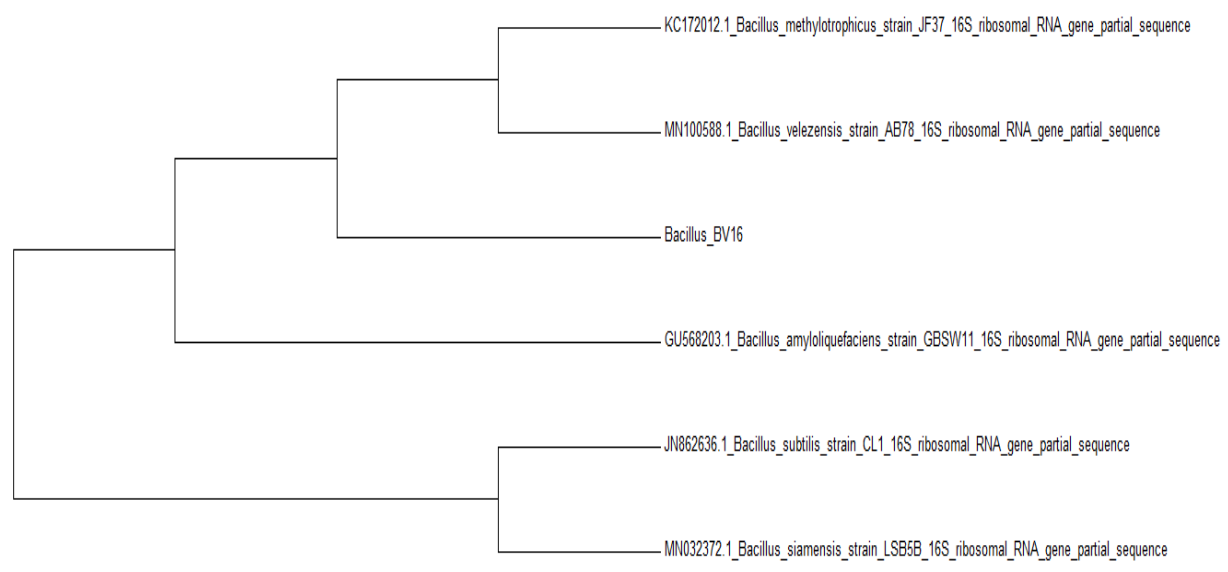

Fig. 3. Phylogenetic relationship based on 16rRNA sequences of BV16

Bacillus velezensis was described as grampositive bacteria with rod-shaped, cell size from $0.7-0.9 \times 1.6-3 \mu \mathrm{m}$, producing acids from aesculin, amygdalin, arbutin [14]. This bacteria was also known as an effective biocontrol agent of plant pathogen with promising ability to produce antibiotics, fungal cell wall - degrading enzymes and plant growth stimulating compounds [15]. The research of Fan et al. [16] summarized that the strain of $B$. velezensis FZB42 and mutants controlled plant pathogens due to different mechanisms including direct antibiosis and competition by secretion of a spectrum of secondary metabolites in the rhizosphere, the beneficial action on the hostplant microbiome and stimulation of plant induced systemic resistance (ISR). Importantly, the harmful effects of Bacillus velezensis to date, have not been reported yet.

\subsection{Extracellular Enzyme Assay of Selected Strain}

An enzyme produced by microorganisms is determined based on the ability to decompose substrates and change the color of the specific media around the bacterial colonies. The ability of chitinase, cellulase and protease - producing 
ability of B.velezensis BV16 strain was screened and the obtained results were presented on Table 2 and Fig. 4.

Table 2. Diameter of clear halos surrounding extracellular enzymes

\begin{tabular}{llll}
\hline Strain & \multicolumn{3}{c}{ Diameter $(\mathrm{cm})$} \\
\cline { 2 - 4 } & Chitinase & Protease & Cellulase \\
\hline BV16 & $2.1 \pm 0.2$ & $1.2 \pm 0.2$ & $2.5 \pm 0.1$ \\
\hline
\end{tabular}

B. velezensis is capable of producing chitinase, protease and cellulase which contributed to fungal cell wall breakdown. The fungal cell wall is a matrix composed of polysaccharides, proteins, and other components, for example, many fungal pathogens belonged to ascomycota and basidiomycota contain mixture of chitin, glucan, and mannoproteins in their cell walls [17], that provide novel structural barriers in order to develop, survive in response to ambient conditions. Therefore, to exhibit antifungal activity, many antagonistic bacteria need to secrete lytic enzymes capable of dissolving fungal cell walls [18]. Especially, proteases also play a key role in the cell lysis process. Proteases bind to the outer mannoprotein layer of the cell wall, open the protein structure, and expose inner glucan layers and chitin microfibrils [10]. Strong activity of chitinase, protease and cellulase in the BV16 strain are therefore consistent with the observed novel growth inhibition of Phytophthora infestans (Fig. 1b).

\subsection{Control Efficiency from Biomass, Extracellular Fluid, Extracellular Enzymes and Non-enzyme Metabolites Produced by Selected Strain against Phytophthora infestans after 7 days}

The results of Table 3 and Fig. 5 showed that there was a significant difference in the inhibitory efficiency against fungal pathogen Phytophthora infestans from the different components of the selected strain $B$. velezensis culture broth including biomass, extracellular fluid, extracellular enzymes and non-enzyme metabolites.

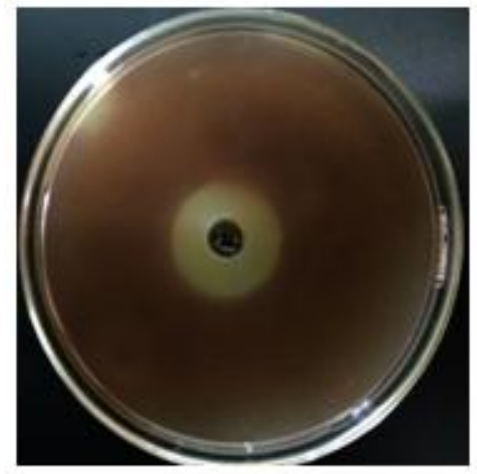

a

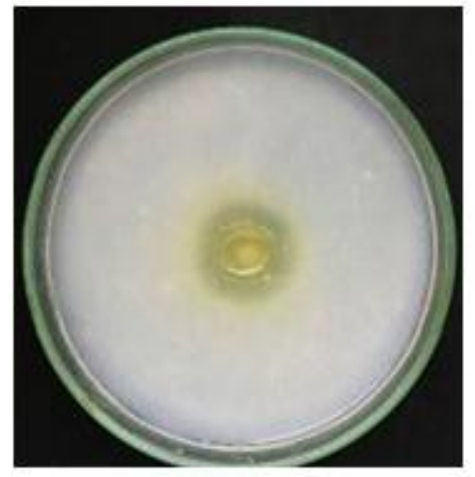

b
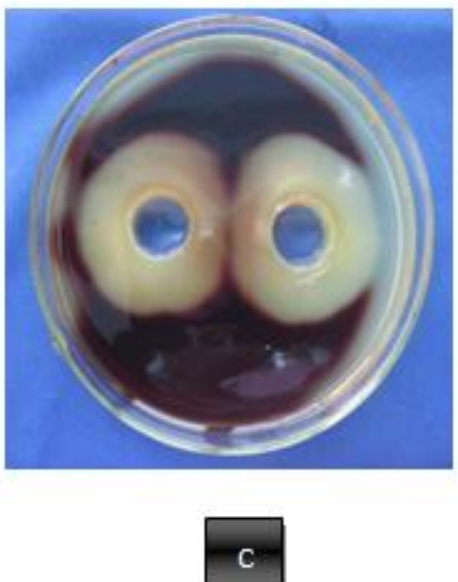

Fig. 4. Production of chitinase (a), protease (b), cellulase (c) by BV16 strain

Table 3. Control efficiency from different components of selected strain $B$. velezensis culture broth against Phytophthora infestans after 7 days

\begin{tabular}{ll}
\hline Treatment & Inhibition of mycelial growth (\%) \\
\hline Control (Phytophthora infestans) & - \\
Biomass $\left(10^{4}\right.$ cells $\left./ \mathrm{mL}\right)$ & $\mathbf{8 4 . 4 4 \pm 2 . 2 2 ^ { \mathrm { a } }}$ \\
Biomass with heat - treantment $\left(10^{4}\right.$ cells $\left./ \mathrm{mL}\right)$ & $66.67 \pm 3.84^{\mathrm{b}}$ \\
Extracellular fluid & $\mathbf{8 0 . 0 0 \pm 2 . 2 2 ^ { \mathrm { a } }}$ \\
Extracellular enzymes & $72.59 \pm 5.59^{\mathrm{b}}$ \\
Extracellular non-enzyme metabolites & $45.18 \pm 3.39^{\mathrm{c}}$ \\
\hline Means $\pm S D=$ Means \pm Standard Deviation of three independent experiences. The mean difference is significant \\
\multicolumn{1}{c}{ at the $p \leq .05$. Means followed by the different letters are significantly different }
\end{tabular}



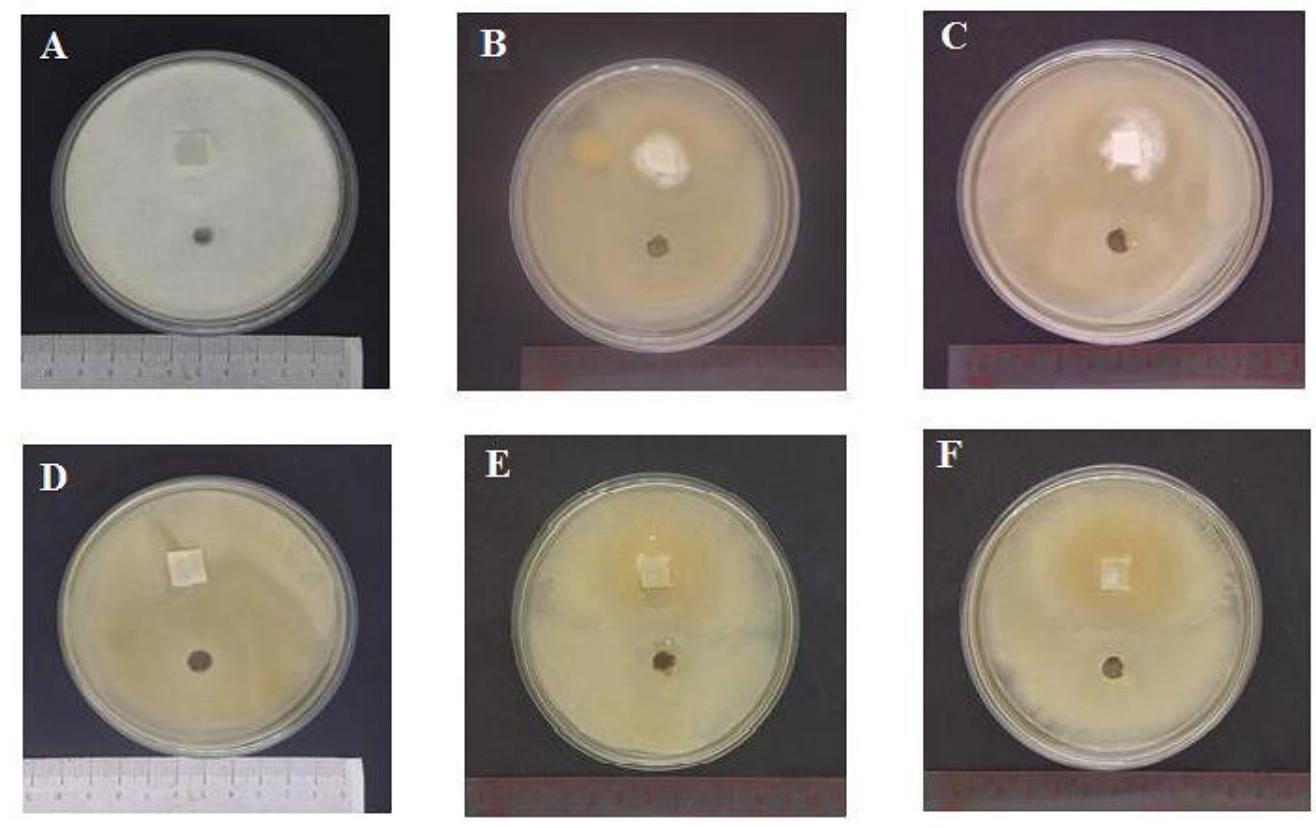

Fig. 5. Potential antifungals in the different components B.velezensis BV 16 culture broth: A. Control; B. Biomass; C. Biomass with heated up to $55^{\circ} \mathrm{C}$; D. Extracellular fluid, E. Extracellular non-enzyme compounds, F. Extracellular enzyme

Among them, the highest inhibitory efficiency was observed at the biomass, making up $84.44 \%$, while bacterial biomass with being heated up to $55^{\circ} \mathrm{C}$ also exhibited the antagonistic ability with $66.67 \%$ of inhibitory efficiency. This can be explained that $B$. velezensis cells could compete strongly nutrition with the fungal pathogen [19]. Besides, in unfavorable conditions (such as being heated), B. velezensis cells could produce spores and release internal metabolites resulting in inhibiting the growth of the fungal pathogen. Furthermore, the result also showed that extracellular fluid of $B$. velezensis BV16 was responsible for $80 \%$ of control efficiency against the fungal disease Phytophthora infestans on tomato crop. This finding was consistent with the previous researches also revealed that potential antifungal metabolites produced by $B$. velezensis could consist of lipopeptide, polyketide, dipeptide, siderophore, difficidin, bacillaene, macrolactin and antimicrobial protein $[20,21,22]$. Especially, the inhibition of mycelial growth of the extracellular enzymes was 1.6 times higher than the figure of extracellular non-enzyme compounds, which was in agreement with the novel capacity of producing some extracellular enzymes of $B$. velezensis BV16 including chitinase, protease and cellualse (Fig. 4).

\section{CONCLUSION}

The present study showed that BV16 was Bacillus velezensis which has known as the most potential antagonistic strain in controlling fungal plant pathogen Phytophthora infestans attacking the tomato tree. The strongest inhibition of mycelial growth on $P$. infestans of Bacillus velezensis BV16 was recorded with $88.89 \%$ of growth inhibition percentage. The results also showed that strong activity of chitinase, protease and cellulase in the BV16 strain are consistent with the novel growth control of Phytophthora infestans. This result will be applied to produce the biological control as the alternative method contributing significantly to the development of sustainable and efficient organic agriculture.

\section{ETHICAL APPROVAL}

This article followed professional ethics within its research. As per international standard or university standard written ethical approval has been collected and preserved by the author(s).

\section{ACKNOWLEDGEMENTS}

We are thankful to The University of Danang, University of Science and Education for supporting this study. 


\section{COMPETING INTERESTS}

Authors have declared that no competing interests exist.

\section{REFERENCES}

1. Burgess LW, Knight TE, Tesoriero L, Phan HT. Diagnostic manual for plant diseases in Vietnam. ACIAR Monograph. 2008;129: 210. ACIAR: Canberra.

2. Childers, Richard, Giovanna Danies, Kevin Myers, Zhangjun Fei, lan M. Small, and William E. Fry. Acquired Resistance to Mefenoxam in Sensitive Isolates of Phytophthora Infestans. Phytopathology. 2015;105(3):342-49.

3. Machado, Carolina S, Brisa M. Fregonesi, Renato IS. Alves, Karina AA Tonani, Jordi Sierra, Bruno S. Martinis, Beatriz S. Celere, Montse Mari, Marta Schuhmacher, Martí Nadal, Jose L. Domingo, and Susana Segura-Muñoz. Health Risks of Environmental Exposure to Metals and Herbicides in the Pardo River, Brazil,. Environmental Science and Pollution Research. 2017;24(25):20160-72.

4. Suganthi C, Mageswari A, Karthikeyan S, Anbalagan M, Sivakumar A, Gothandam KM. Screening and Optimization of Protease Production from a Halotolerant Bacillus Licheniformis Isolated from Saltern Sediments. Journal of Genetic Engineering and Biotechnology. 2013;11(1):47-52.

5. van der Werf, Hayo MG, Christophe Zimmer. An Indicator of Pesticide Environmental Impact Based on a Fuzzy Expert System. Chemosphere. 1998; 36(10):2225-49

6. Carey, Ann E, Frederick W. Kutz. Trends in Ambient Concentrations of Agrochemicals in Humans and the Environment of the United States. Environmental Monitoring and Assessment. 1985;5(2):155-63.

7. Gong, Peng, Lu Liang, Qiang Zhang. China Must Reduce Fertilizer Use Too. Nature. 2011;473(7347):284-85

8. Elad, Yigal, Stanley Freeman. Biological Control of Fungal Plant Pathogens. Agricultural Applications. Berlin, Heidelberg: Springer Berlin Heidelberg. 2002;93-109.

9. THAN, Phyu Phyu, Carmelo S. DEL CASTILLO, Takeshi YOSHIKAWA, and Taizo SAKATA.. Extracellular Protease Production of Bacteriolytic Bacteria
Isolated from Marine Environments. Fisheries Science. 2004;70(4):659-66.

10. Han, Joon-Hee, Hongsik Shim, Jong-Hwan Shin, Kyoung Su Kim. Antagonistic Activities of Bacillus Spp. Strains Isolated from Tidal Flat Sediment Towards Anthracnose Pathogens Colletotrichum Acutatum and C. Gloeosporioides in South Korea. The Plant Pathology Journal. 2015; 31(2):165-75.

11. Hsu SC, Lockwood JL. Powdered Chitin Agar as a Selective Medium for Enumeration of Actinomycetes in Water and Soil. Applied Microbiology. 1975;29(3): 422-26.

12. Teather RM, Wood PJ. Use of Congo RedPolysaccharide Interactions in Enumeration and Characterization of Cellulolytic Bacteria from the Bovine Rumen. Applied and Environmental Microbiology. 1982;43(4):777-80.

13. Caulier, Simon, Annika Gillis, Gil Colau, Florent Licciardi, Maxime Liépin, Nicolas Desoignies, Pauline Modrie, Anne Legrève, Jacques Mahillon, and Claude Bragard. Versatile Antagonistic Activities of Soil-Borne Bacillus Spp. and Pseudomonas Spp. against Phytophthora Infestans and Other Potato Pathogens. Frontiers in Microbiology. 2018;9:143.

14. Wang LT, FL Lee CJ. Tai, Kuo HP. Bacillus Velezensis Is a Later Heterotypic Synonym of Bacillus Amyloliquefaciens. International Journal of Systematic and Evolutionary Microbiology. 2008;58(3): 671-75.

15. McSpadden Gardener, Brian B. Ecology of Bacillus and Paenibacillus Spp. in Agricultural Systems. Phytopathology®. 2004;94(11):1252-58.

16. Fan, Ben, Cong Wang, Xiaofeng Song, Xiaolei Ding, Liming Wu, Huijun Wu, Xuewen Gao, and Rainer Borriss. 2018. Bacillus Velezensis FZB42 in 2018: The Gram-Positive Model Strain for Plant Growth Promotion and Biocontrol, Frontiers in Microbiology, 2018;9:2491.

17. Vega, Karina, Markus Kalkum. Chitin, Chitinase Responses, and Invasive Fungal Infections. International Journal of Microbiology. 2012;1-10.

18. $\mathrm{Xu}$, Sheng Jun, Sae Jin Hong, Woobong Choi, and Byung Sup Kim. Antifungal Activity of Paenibacillus Kribbensis Strain T-9 Isolated from Soils against Several Plant Pathogenic Fungi. The Plant Pathology Journal. 2014;30(1):102-8. 
19. Adeniji, Adetomiwa Ayodele, Du Toit Loots, and Olubukola Oluranti Babalola. Bacillus Velezensis: Phylogeny, Useful Applications, and Avenues for Exploitation. Applied Microbiology and Biotechnology, 2019;103(9):3669-82.

20. Arguelles-Arias, Anthony, Marc Ongena, Badre Halimi, Yannick Lara, Alain Brans, Bernard Joris, and Patrick Fickers. 2009. Bacillus Amyloliquefaciens GA1 as a Source of Potent Antibiotics and Other Secondary Metabolites for Biocontrol of Plant Pathogens. Microbial Cell Factories, 2009;8(1):63.

21. Yuan, Jun, Waseem Raza, Qiwei Huang, Qirong Shen. The Ultrasound-Assisted
Extraction and Identification of Antifungal Substances from B. Amyloliquefaciens Strain NJN-6 Suppressing Fusarium Oxysporum. Journal of Basic Microbiology. 2012;52(6):721-30.

22. Yuan, Jun, Yunze Ruan, Beibei Wang, Jian Zhang, Raza Waseem, Qiwei Huang, and Qirong Shen. Plant Growth-Promoting Rhizobacteria Strain Bacillus Amyloliquefaciens NJN-6-Enriched BioOrganic Fertilizer Suppressed Fusarium Wilt and Promoted the Growth of Banana Plants. Journal of Agricultural and Food Chemistry. 2013;61(16):377480.

(c) 2020 Khanh et al.; This is an Open Access article distributed under the terms of the Creative Commons Attribution License (http://creativecommons.org/licenses/by/4.0), which permits unrestricted use, distribution, and reproduction in any medium, provided the original work is properly cited.

Peer-review history:

The peer review history for this paper can be accessed here: http://www. sdiarticle4.com/review-history/63056 